\title{
The combination therapy of targeting both paclitaxel and Dendrophthoe pentandra leaves extract nanoparticles for improvement breast cancer treatment efficacy by reducing TUBB3 and MAP4 expressions
}

\author{
Sofy Permana ${ }^{\bigotimes}$, Hilmia Lukman², Eviana Norahmawati ${ }^{3}$, Oktavia Eka Puspita4, Dicky Faisal \\ Moh Al Zein 5 , Yoshiyuki Kawamoto 6 and Agustina Tri Endharti7 \\ 1Department of Biology, Faculty of Mathematics and Natural Sciences, Universitas Brawijaya, Indonesia; ${ }^{2}$ Master Program in Biomedical Sciences, \\ Faculty of Medicine, Universitas Brawijaya, Indonesia; ${ }^{3}$ Department of Pathology Anatomy, Faculty of Medicine, Universitas Brawijaya, Indonesia; \\ ${ }^{4}$ Study Program of Pharmacy, Faculty of Medicine, Universitas Brawijaya, Indonesia; ${ }^{5}$ Bachelor Program of Biology, Faculty of Mathematics and \\ Natural Sciences, Universitas Brawijaya, Indonesia; ${ }^{6}$ Department of Biomedical Sciences, Graduate School of Life and Health Sciences, Chubu \\ University Japan; 7Department of Parasitology, Faculty of Medicine, Universitas Brawijaya, Indonesia, Biomedical Central Laboratory, Faculty of \\ Medicine, Universitas Brawijaya, Indonesia
}

The aim of this study is to investigate the combination treatments of paclitaxel and chitosan-Dendrophthoe pentandra leaves extract nanoparticles (NPDP) on MCF-7 breast cancer cells. Chitosan-NPDP nanoparticles were characterized by Fourier-transform infrared (FTIR), scanning electron microscopy (SEM), and assessed by using immunofluorescence microscopy. MCF-7 cells are cultured and divided into six groups: group 1 was a negative control (without paclitaxel or NPDP); group 2 was treated with paclitaxel alone; groups 3-5 were treated with $\operatorname{NPDP}(2,4$, and $8 \mathrm{mg} / \mathrm{mL}$, respectively) and group 6 was treated only by $8 \mathrm{mg} / \mathrm{mL}$ of chitosan-NPDP nanoparticles. The proliferation and cell cycle were analyzed by flow cytometry and the expression of TUBB3 and MAP4 were assessed by immunofluorescence microscopy. The combinations of paclitaxel-NPDP significantly inhibit proliferation of cells $(P<0.001)$ and it is able to induce $G 2 / M$ cell cycle arrest $(P<0.001)$. The combination of paclitaxelNPDP significantly decreases the expressions of TUBB3 $(P<0.001)$ and MAP4 $(P<0.001)$ in MCF-7 cells. These results indicate that the combination of NPDP nanoparticles could reduce the expressions of TUBB3 and MAP4. This research may provide possible sources of new therapy for NPDP.

Keywords: cell cycle, Dendrophthoe pentandra, MAP4, proliferation, TUBB3

Received: 06 December, 2020; revised: 22 March, 2021; accepted: 04 May, 2021; available on-line: 15 July, 2021

⿶e-mail: sofy-bio@ub.ac.id

Acknowledgments of Financial Support: This study was supported by grants from the Directorate General of Higher Education, Ministry of Education and Culture Project.

Abbreviations: AKT, Protein Kinase B; DPE, Dendrophthoe pentandra Extract; EGF, Epidermal Growth Factor; ERK, Extracellular Signal-Regulated Kinases; MAP4, Microtubule Associated Protein 4; MAPK, Mitogen-Activated Protein Kinase; MCF-7, Michigan Cancer Foundation-7; NPDP, Nanoparticles Chitosan- Dendrophthoe pentandra Leaves extract; PI3K, Phosphoinositide 3-kinase; TPP, Tripolyphosphate; UBB3, ßIII-tubulin

\section{INTRODUCTION}

Breast cancer is a common disease in the world and the second leading cause of death from cancer (Abdulkareem, 2013). One of the chemotherapy drugs for breast cancer is paclitaxel and it acts as an antitumor by encouraging polymerization and microtubule stabilization (Calaf et al., 2018; Tang et al., 2017). Despite its effectiveness against cancer, paclitaxel has other side effects including fatigue, myalgia, arthralgia, nausea, and neutropenia (Sibaud et al., 2016). Hence, using paclitaxel combined with other medications, to minimize the side effects or to function synergistically, improves paclitaxel's effects. Dendrophthoe pentandra, a mango-growing parasitic plant, has commonly been used as a medicinal plant for treating asthma, measles, cough, skin infections and has been used as a diuretic and an anticancer agent (Artanti et al., 2012). Dendrophthoe pentandra contains both of kaempferol-3-0-alpha-L-rhamnopyranoside and quercetin-3-0-alpha-L-rhamnopyranoside to prevent colon cancer proliferation (Wiart, 2012; Endharti et al., 2018a). The combination with doxorubicin decreased survivin and $\mathrm{iCa}^{2+}$ concentrations (Endharti et al., 2016).

Microtubules were identified as a cancer treatment target to inhibit cell division (Endharti \& Permana, 2017). Tubulin BIII (TUBB3) is the most studied microtubule isotype in human cancer. TUBB3 over-expression was linked to poor clinical results in several cancers (Karki \& Ferlini, 2014). Microtubule-associated protein 4 (MAP4) was a cytosolic microtubule which plays a significant role in maintaining vascular stability and tumorigenesis (Eduardo et al., 2017; Zhang et al., 2019). Therefore, a drug delivery system which could selectively bring appropriate concentrations of drugs into the targeted cells is needed to increase bioavailability and to reduce the side effects. Nanoparticles may be the therapeutic alternative in this aspect (Cordero et al., 2019; Tang et al., 2017). It is expected that chitosan, an abundant biopolymer as a drug carrier, will evolve and improve the stability, bioavailability, and therapeutic effectiveness of various conditions (Da Silva et al., 2013; Rampino et al., 2013).

The efficacy of the combination of nanoparticles chitosan - Dendrophthoe pentandra Leaves Extract (NPDP) and paclitaxel as an anti-cancer treatment is still unclear. In this study, we investigated the effects of paclitaxel and chitosan-NPDP nanoparticles combination on TUBB3 and MAP4 in MCF-7 breast cancer cells. 


\section{MATERIALS AND METHODS}

\section{Plant material and extraction}

Fresh leaves of Dendrophthoe pentandra have been collected in Probolinggo, East Java, Indonesia and identified at the Department of Biology, Universitas Brawijaya (specimen No. 0170/Taxonomy Identification/03/2015). The Dendrophthoe pentandra leaves were extracted according to Endharti and others (Endharti et al., 2018). Briefly, Dendrophthoe pentandra ethanol extract from crushed dried shade leaves was filtered and centrifuged at 5000 rpm for 15 minutes at room-temperature and evaporated at $60 \pm 5^{\circ} \mathrm{C}$.

\section{Preparation of chitosan-NPDP nanoparticles}

The chitosan nanoparticles were prepared with sodium tripolyphosphate (TPP, Sigma-Aldrich, St. Louis, USA) by using the ionic gelation process. Briefly, 2 gram of chitosan (Sigma-Aldrich, USA) was dissolved in $500 \mathrm{ml}$ of $1 \%$ acetic acid solution and stirred at 1000 $\mathrm{rpm}$ at room temperature for 25 minutes until the solution became clear. The resulting solution was sonicated before being titrated with a $\mathrm{pH} 5 \mathrm{NaOH}$ solution and filtered through a 0.2 mesh filter. Then, $50 \mathrm{~g}$ of Dendrophthoe pentandra extract (DPE) was added to chitosan-acetic acid solution. Thereafter, in the solution stirring state at room temperature, $2 \%$ TPP (w/v) was applied in droplets. By adding the TPP solution to the magnetic stirrer with chitosan solution at $60^{\circ} \mathrm{C}$, the resulting nanoparticles and solutions were filtered through a 0.2 mesh filter. Dissolution of $1.2 \%$ Tween 80 and $2 \%$ acetic acid were used to dissolve Chitosan $(0.17-0.18 \% \mathrm{w} / \mathrm{v})$. For 72 hours the solution was put in a bath sonicator with a magnetic stirrer for 24 hours. Sodium sulphate was then applied and stirred for 1 hour, then sonicated again for 15 minutes. The nano-sized particles were precipitated. Nanoparticles loaded with $100 \mathrm{ml}$ of leaf extract are centrifuged at $5000 \mathrm{rpm}$ for 15 minutes at $4^{\circ} \mathrm{C}$. The pellet $(6 \mathrm{mg} / \mathrm{ml})$ was taken into normal saline with the 0.5 $\mathrm{mg} / \mathrm{ml}$ of extract and then resuspended. The suspension was stirred by a magnetic stirrer at $400 \mathrm{rpm}$ for 4 hours and later centrifuged to get loaded nanoparticles.

\section{Imaging-Based Evaluation of chitosan-NPDP}

The extracted chitosan-NPDP was characterized by various analytical methods. FT-IR spectra of newly formed chitosan-NPDP nanoparticles were obtained with 64 scans at a resolution of $4.0 \mathrm{~cm}^{-1}$ and the spectrum was recorded at a wavelength of $500-4000 \mathrm{~cm}$ (PerkinElmer Spectrum 100 FTIR spectrometer, PerkinElmer Inc., Waltham, MA, USA).

To know the interaction between DPE extract and chitosan, the formation of chitosan-NPDP was further confirmed using the FTIR spectrum. The surface morphology of chitosan-NPDP was studied using a SEM (JSM 7800F, JEOL Ltd., Tokyo, Japan) with a $5 \mathrm{kV}$ accelerating voltage. Using a gold sputtering unit, the test samples (chitosan-NPDP) were placed onto the surface of silicon chips and coated with gold. The operating condition was an accelerated voltage of $5 \mathrm{kV}$, a pressure of 7 bar and a deposition current of $20 \mathrm{~mA}$.

\section{Cell cultures}

The American Type Culture Collection (ATCC) (Bioresource Centre, Manassas, VA, USA) has obtained human breast cancer cells (MCF-7) cultured in Roswell
Park Memorial Institute 1640 medium (RPMI 1640) (Gibco, USA) supplemented with 10\% Fetal Bovine Serum (FBS) (Chemical Co., St. Louis, MO, USA), 100 U/ $\mathrm{ml}$ amphotericin and $100 \mathrm{U} / \mathrm{ml}$ penicillin (Gibco, USA). In a $5 \% \mathrm{CO} 2$ incubator at $37^{\circ} \mathrm{C}$, cells were incubated in humidified air.

\section{Antibodies}

The primer antibody used in the research was monoclonal mouse anti-TUBB3 (Santa Cruz Biotechnology, Inc., USA) for $\beta$ III tubulin and rabbit anti-MAP4 (Bioss Inc., USA) for MAP4, while the secondary antibody was conjugated to mouse IgG with fluorescein (Rockland, USA).

\section{The Assessment of Cytotoxicity by MTT Assay}

Cytotoxicity by MT'T assay was performed using the Endharti protocol (Endharti et al., 2019). Briefly, cells were seeded in the 96-well culture plate at a concentration of $5 \times 10^{4}$ cells $/ \mathrm{mL}$ and treated with $0.5-16 \mu \mathrm{g} /$ $\mathrm{mL}$ paclitaxel in single treatment or in combination with NPDP $(2,4$ or $8 \mathrm{mg} / \mathrm{mL})$, and then cells were cultured for 24 hours at $37^{\circ} \mathrm{C}$ in $5 \% \mathrm{CO}_{2}$ and $95 \%$ humidity. Next, $100 \mu \mathrm{L} /$ well of the 3-(4,5-dimethylthiazol2-yl)-2,5-diphenyltetrazolium bromide reagent (MTT, Sigma Chemical Co., St. Louis, MO, USA) was applied to the respective wells at a concentration of $0.5 \mathrm{mg} / \mathrm{mL}$ and incubated for 4 hours at $37^{\circ} \mathrm{C}$ in the $\mathrm{CO} 2$ incubator. Approximately $100 \mu \mathrm{L}$ of dimethyl sulfoxide (DMSO) was applied to make the formazan easily soluble. ELISA reader was used to assess the optical density (OD) at $630 \mathrm{~nm}$. The percentage inhibition was calculated using the formula: (OD of control - OD of sample/OD of control) $\times 100$.

\section{Cell Proliferation Assay}

Proliferation assay was performed using Ki67 labeling. Briefly, $1 \times 10^{5}$ cells were seeded in the 24 -well culture plate and treated with $0.5-16 \mu \mathrm{g} / \mathrm{mL}$ paclitaxel in single treatment or in combination with NPDP (2, 4 or 8 $\mathrm{mg} / \mathrm{mL}$ ), and then cells were cultured for 24 hours at $37^{\circ} \mathrm{C}$ in $5 \% \mathrm{CO}_{2}$ and $95 \%$ humidity. Then, cells were harvested and centrifuged for 5 minutes at $200 \times g$. Cells were re-suspended in $200 \mu \mathrm{l}$ fixation solution and subsequently incubated at room temperature for 20 minutes. Cells were permeabilized in $200 \mu \mathrm{l}(10 \mathrm{mM}$ HEPES) and incubated at room temperature for 20 minutes followed by FITC conjugated-Ki67 (Bioscience) incubation at $4^{\circ} \mathrm{C}$ for 20 minutes in the dark. Cells were washed twice with HBSS containing 5\% FBS and $0.1 \%$ sodium azide. For DNA staining, cells were stained with $(0.5 \mathrm{mg} / \mathrm{ml})$ Propidium Iodide (PI, Sigma Chemical Co., St. Louis, MO, USA) at $4^{\circ} \mathrm{C}$ for 20 minutes. Cells were analyzed after staining using FACS Calibur (Becton Dickinson) flow cytometer and Cell Quest software.

\section{Cell Cycle Analysis}

The progression of the cell cycle was assessed by labeling with anti-BrdU conjugated with FITC and staining with Propidium Iodide, according to a method by Endharti and others (Endharti et al., 2016). Briefly, MCF cells were seeded at $1 \times 10^{5}$ cells per well in 24 well plates and treated with $0.5-16 \mu \mathrm{g} / \mathrm{mL}$ paclitaxel in single treatment or in combination with NPDP $(2,4$ or $8 \mathrm{mg} / \mathrm{mL})$, and then cells were cultured for 24 hours at $37^{\circ} \mathrm{C}$ in $5 \% \mathrm{CO}_{2}$ and $95 \%$ humidity. After 24 hours incubation, cells were suspended in cold $70 \%$ ethanol for 40 minutes. The cells 


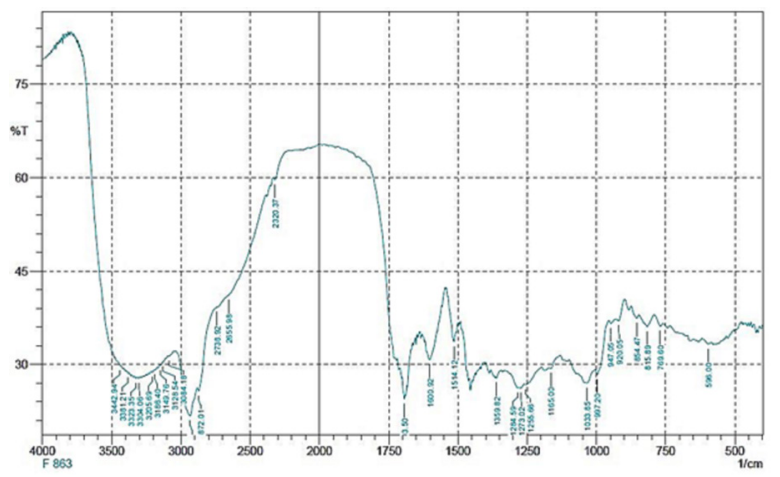

Figure 1. Assessment of NPDP was employing FTIR.

To analyze stability of chitosan-NPDP nanoparticles, the suspension was determined by the pattern of molecules as described in Materials and Methods section. FTIR analysis was performed on paclitaxel powders, PLDLA microspheres, and PLDLA microspheres filled with paclitaxel using a spectrophotometer model ATRFTIR Perkin-Elmer 100S. In a $\mathrm{KBr}$ pellet, samples were taken and scanned in the IR range of 600 to $4000 \mathrm{~cm}^{-1}$.

were centrifuged and re-suspended in $2 \mathrm{M} \mathrm{HCl}$ at $37^{\circ} \mathrm{C}$ followed by incubation with $0.1 \mathrm{M}$ sodium tetraborate $(\mathrm{pH}=8.5)$ for 10 minutes at room temperature. Cells were then permeabilized with $0.1 \%$ Tween-20 1\% BSA in PBS for 5 minutes at room temperature, followed by the addition of anti-BrdU (Biolegend). For DNA staining, $0.5 \mathrm{mg} / \mathrm{ml}$ propidium iodide (PI, Sigma Chemical Co., St. Louis, MO, USA) and $1 \mathrm{mg} / \mathrm{ml}$ RNase (Sigma Chemical Co., St. Louis, MO, USA) were incubated for 30 minutes. The cells were eventually assessed using a BD FACS Calibur cytometer (Becton Dickinson, San Jose, CA, USA). The percentage of cells in each phase of the cell cycle was quantitated using Cell Quest Pro software.

\section{Immunofluorescence microscopy}

MCF-7 cells were seeded on a glass coverslip on chamber plates and after an overnight incubation cells were treated with NPDP for 48 hours. The glass coverslips were fixed with $4 \%$ formaldehyde for $15 \mathrm{~min}$ utes, followed by permeabilization with $0.5 \%$ Triton X-100 for 15 minutes at room temperature. The cells were blocked with 1\% BSA for 1 hour in bovine serum albumin (BSA, Sigma, Chemical Co., St. Louis, MO, USA). Primary antibody was applied overnight at $4^{\circ} \mathrm{C}$, followed by incubation with fluorescein conjugated secondary antibody for 1 hour. The nuclei were co-stained with 4',6-diamidino-2-phenylindole (DAPI, Bio Legend, USA) and visualized by using Fluorescence microscopy
(OLYMPUS 1X71). Fluorescence quantifications were analyzed by using ImageJ 2 software.

\section{Statistics}

Experiments were conducted at least three times. Data were expressed as the mean \pm S.D., andnormality was tested using the Kolmogorov-Smirnov test. Variables with a non-normal distribution were logarithmically transformed before statistical analysis. The data among multiple groups were analyzed using one-way analysis of variance (ANOVA) followed by post hoc test. Independent significance was defined as a $P$-value $<0.05$. All statistical analyses were performed using SPSS 17.0 software.

\section{RESULTS}

\section{FTIR characterization of chitosan-NPDP nanoparticles}

This study detected the elements and functional groups in the ethanol extract. The Fourier transform infrared (FTIR) spectrum of chitosan-NPDP nanoparticles was shown in (Fig. 1). In chitosan-NPDP nanoparticles spectrum the peak of $\mathrm{OH}$ and $\mathrm{NH}$ group was at 3200 $3600 \mathrm{~cm}^{-1}$. The peak of amide group was seen at 1655 $\mathrm{cm}^{-1}$. The peak of $-\mathrm{P}=\mathrm{O}$ groups of polyphosphate anion and C-N aliphatic amines were seen at $1273 \mathrm{~cm}^{-1}$ and $1033 \mathrm{~cm}^{-1}$, respectively.

\section{SEM Analysis}

The morphology of chitosan- NPDP nanoparticle was observed and shown in (Fig. 2). SEM analysis showed that the particles were nearly spherical in shape.

\section{Cytotoxic activity of paclitaxel- NPDP combined of MCF-7 cell lines}

MT'T assay was used to assess the effectiveness of paclitaxel-NPDP mediated inhibition of MCF-7 cell production. The cytotoxic activity against MCF-7 cell line was evaluated at different concentrations of NPDP. NPDP nanoparticles have established anticancer activities with or without NPDP. Cell viability was decreased in a dose-dependent manner of each group, when it was compared to the control. The anticancer activity of paclitaxel and NPDP could kill MCF-7 cells by 13\%, 29\%, and $87 \%$, respectively (Fig. 3).

\section{Paclitaxel-NPDP combined Inhibits Cell Proliferative of MCF-7}

In this study, MCF-7 cells proliferation was observed by using Ki67 staining performed by flow cytometer. a

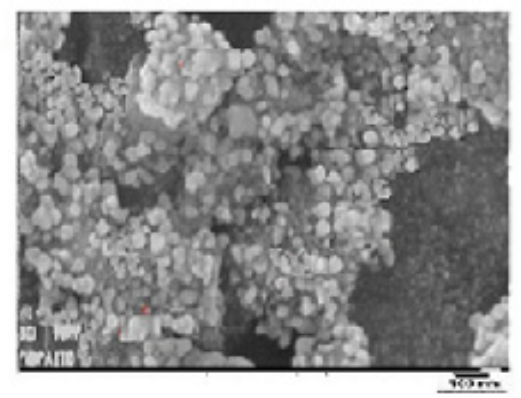

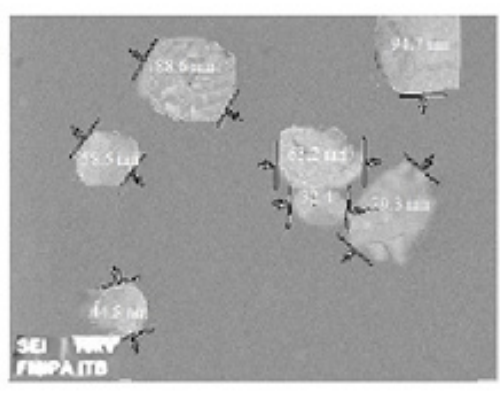

b

Figure 2. SEM analysis of chitosan nanoparticles were synthesized in the presence of NPDP. (a) SEM analysis 5.000X magnification. (b) SEM analysis $10.000 \times$ magnification. 
a

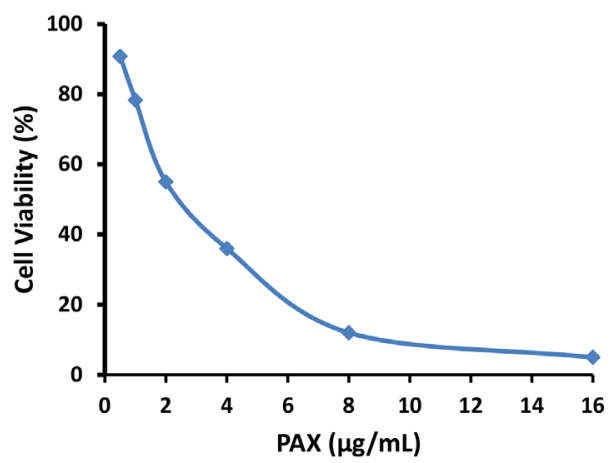

b

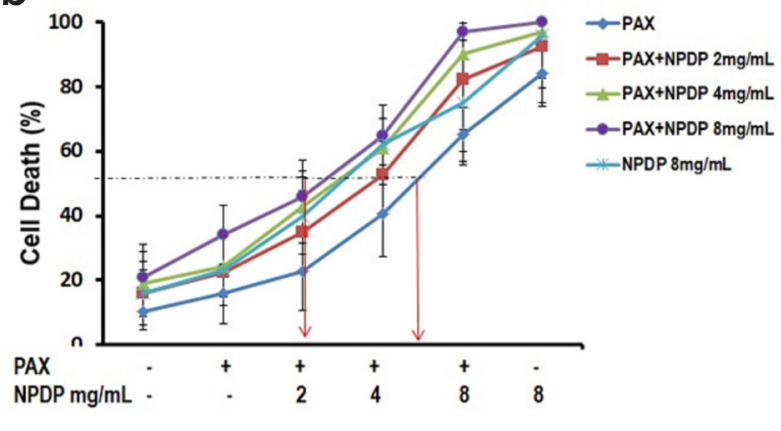

Figure 3. The combination of NPDP with paclitaxel induced cell death in MCF-7 cell line.

(a) Cells were seeded in the 96-well culture plate at a concentration of $5 \times 10^{4}$ cells $/ \mathrm{mL}$ and treated with $0.5-16 \mu \mathrm{g} / \mathrm{mL}$ paclitaxel. The effect of paclitaxel on MCF-7 cell viability was assessed by MTT assay after 24 hours of treatment. (b) MCF-7 cell line was treated in single or combination with NPDP ( $2 \mathrm{mg} / \mathrm{mL}, 4 \mathrm{mg} / \mathrm{mL}$, and $8 \mathrm{mg} / \mathrm{mL}$ ) respectively) immediately after paclitaxel. Dose responses of NPDP showed cytotoxic effects. Results are value of means \pm S.D. from four independent wells and a representative of four individual experiments. ${ }^{*} P<0.05 ;{ }^{* *} P<0.001$.

a

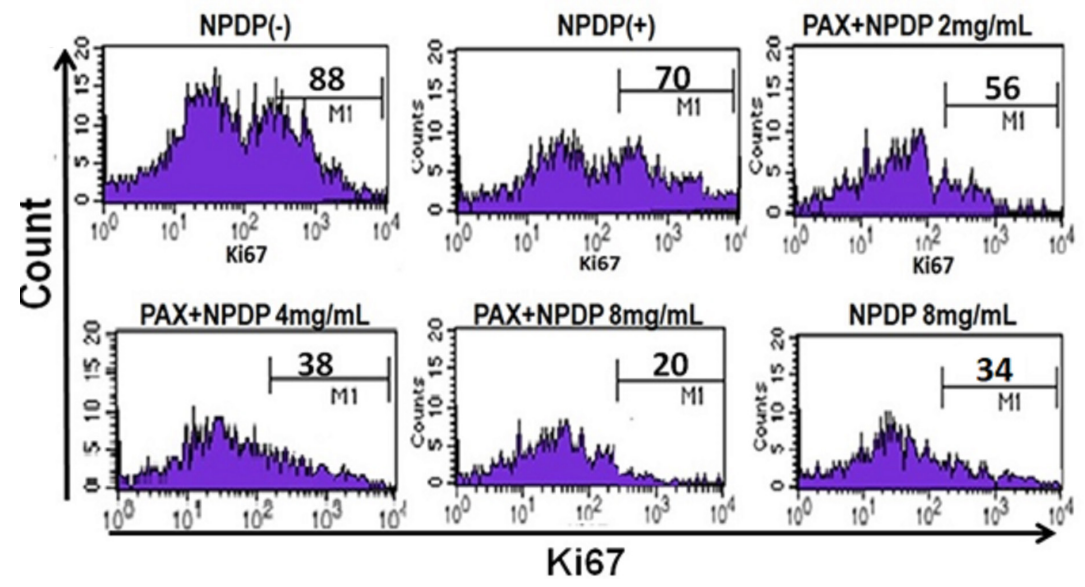

b

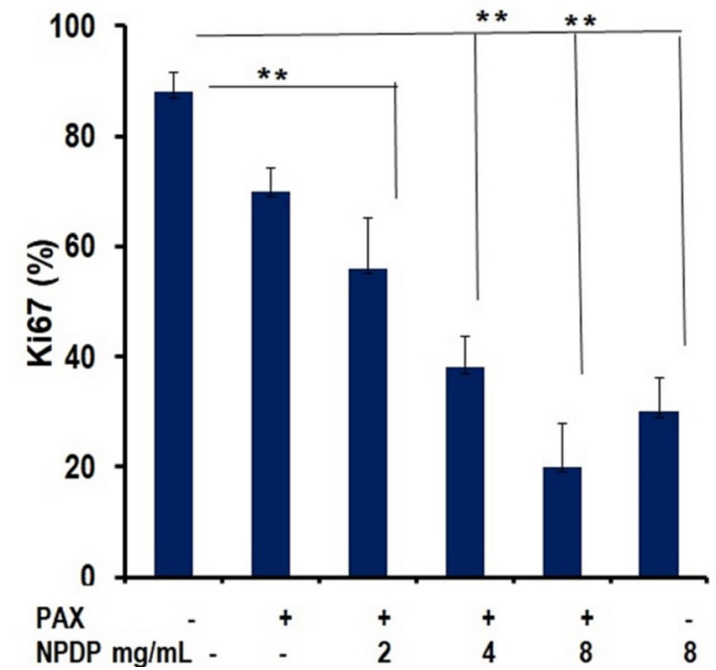

Figure 4. The effect of paclitaxel and NPDP combinations to inhibit cell proliferation

(a) MCF-7 cells were treated with paclitaxel single or combination with NPDP 2, 4, and $8 \mathrm{mg} / \mathrm{mL}$, respectively. (b) At the end of the incubation period, the cells were labelled with Ki67 and propidium iodide (PI). The proliferation of cells was determined by flow cytometer as described in Methods. Cells were scored as percentage proliferation of cells in each of panel. Histogram from representative samples is illustrated for the comparison in Ki67+ cells. (b) Results are value of means \pm S.D. from four independent experiments. ${ }^{*} P<0.05 ;{ }^{* *} P<0.001$.
MCF-7 cells proliferation was significantly higher in $\mathrm{Pa}-$ clitaxel single group than Paclitaxel-NPDP-combined groups $(P<0.001)$ (Fig. 4$)$. It suggests that the combination therapy of Paclitaxel-NPDP suppressed cell viability by reducing the proliferation of $\mathrm{MCF}-7$ cells.

\section{Paclitaxel-NPDP combination Induces MCF-7 Cells Cycle Arrest in G2/M Phase}

For further studies, the cell cycle distribution after paclitaxel-NPDP conjugation was investigated using a flow cytometer. The data demonstrated that the percentage of cells arrested in $G_{2} / M$-phase significantly increased in the groups that were treated with paclitaxel-NPDP compared to the untreated one or control $(P<0.001)$. These results indicated that paclitaxel-NPDP combination promoted arresting the cell cycle in the $G_{2} / M$-phase (Fig. 5).

\section{The combination effect of paclitaxel and NPDP diminish TUBB3 expression}

The expression of TUBB3 was assessed by immunofluorescence microscopy. The data of TUBB3 (Fig. 6a and $6 \mathrm{~b}$ ) confirmed that TUBB3 expression was significantly decreased with paclitaxel and various concentrations of NPDP treatments $(2,4$, and $8 \mathrm{mg} / \mathrm{mL}$, respectively). Compared to the control group, the percentage of TUBB3 expression in combination therapy groups decreases by $60 \%(P<0.001)$ 
a

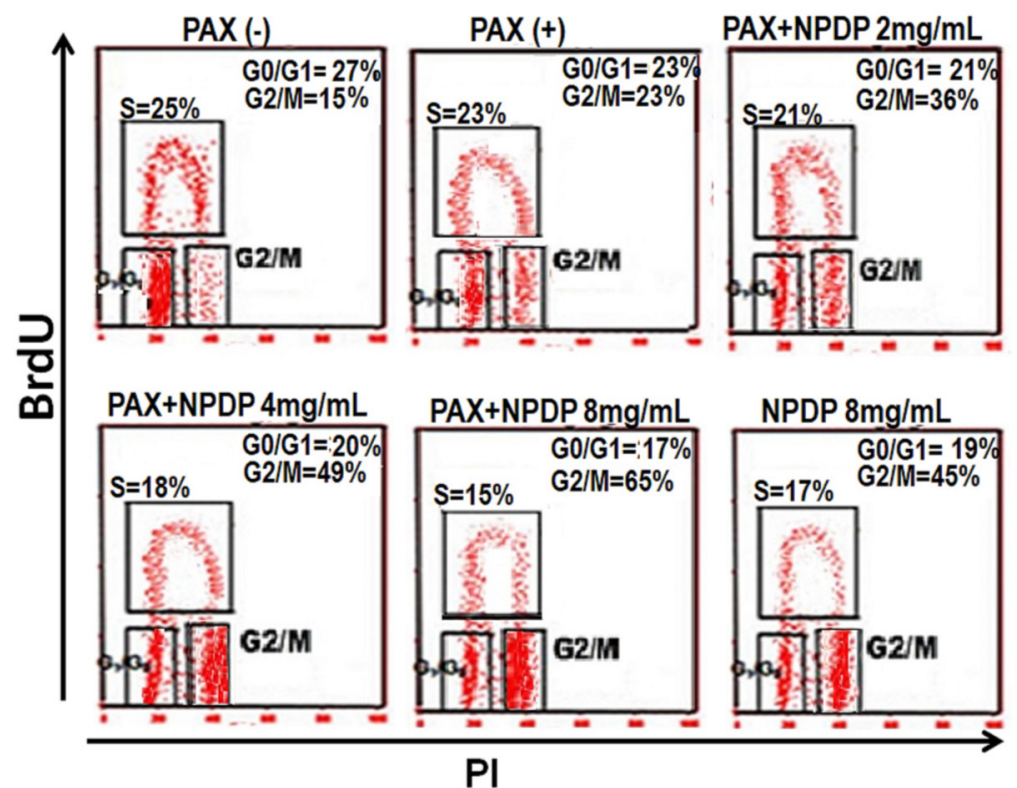

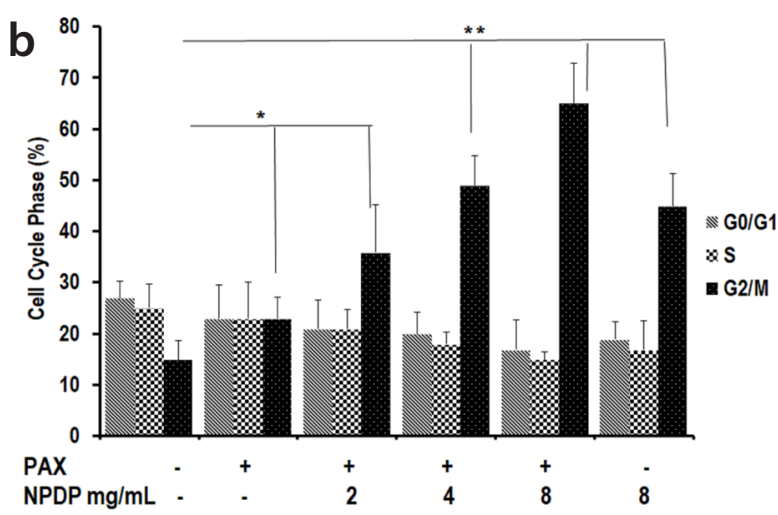

Figure 5. Cell cycle analysis of MCF-7 cell treated with paclitaxel was combined with or without NPDP.

The harvest cells assessed with BrdU followed by labelling with a FITC conjugated anti-BrdU antibody and Propidium lodide were analysed as described in Materials and Methods and (a) the percentages of S phase, G0/G1 and G2/M in the areas have been shown. (b) Results are mean values \pm S.D. from four independent experiments. ${ }^{*} P<0.05,{ }^{* *} P<0.001$ versus control group.

The expressions of MAP4 were reduced with paclitaxel and NPDP

MAP4 expression was assessed by immunofluorescence microscopy. The data of MAP4 (Fig. 7a and 7b) confirmed that expression of MAP4 significantly decreased with paclitaxel and various concentrations of NPDP nanoparticles (2, 4, and $8 \mathrm{mg} / \mathrm{mL} \mathrm{mL}$, respectively). Compared to the control group, the percentage of MAP4 expression in combination therapy groups significantly decreases by $80 \%(P<0.001)$

\section{DISCUSSIONS}

The chitosan nanoparticles were prepared by ionic gelation method. NPDP nanoparticles are formed due to the interaction between positive charged chitosan and negative charged TPP (Agarwal et al., 2018).

According to the results of FTIR analysis, the 3200 $\mathrm{cm}^{-1}$ peak of $\mathrm{OH}$ and $\mathrm{NH}$ bonds in chitosan shifted to
$3200-3600 \mathrm{~cm}^{-1}$ in NPDP nanoparticles. This result indicated that hydrogen bonding is enhanced due to hydrostatic interaction between amino groups and phosphoric groups in TPP (Agarwal et al., 2018; El Aziz et al., 2018). The $1655 \mathrm{~cm}^{-1}$ peak of amide bending vibrations of chitosan shifted to $1693 \mathrm{~cm}^{-1}$. The shift attributed to interaction between chitosan amide with added polygons of TPP. The observed absorption bands at $1273 \mathrm{~cm}^{-1}$ and $1033 \mathrm{~cm}^{-1}$ have been assigned to $-\mathrm{P}=\mathrm{O}$ groups of polyphosphate anion and $\mathrm{C}-\mathrm{N}$ aliphatic amines, respectively (Chandirika et al., 2018; Ibezim et al., 2011).

When the SEM images obtained for NPDP nanoparticles were examined, it was seen that a very regular pore structure was formed on the surface. The result of SEM has showed the surface morphology of freeze-dried NPDP nanoparticles. There are almost spherical shaped nanoparticles. In accordance with our previous studies, the freeze-dried nanoparticles have diameters less than $1 \mu \mathrm{m}$. (Da Silva et al., 2015). This was due to the aggregation caused by heavy inter- and intra-molecular bonding of hydrogen that could not be stopped even with the homogenization of the vortex (El Aziz et al., 2018).

In this study, we investigated the effects of Paclitaxel and NPDP on the proliferation and cell cycle of MCF-7 cells and its intrinsic mechanism. Previous study proved that Dendroptoe pentandra contains quercetin-3-rhamnose, which has anti-cancer effects. Quercetin has potent anticarcinogenic properties and is known to contribute as a proliferation inhibitor (Endharti et al., 2016). Quercetin also improves the action of 5-Fluorouracil (5-FU) promoting increased apoptosis in breast cancer T47D cells (Endharti et al., 2018b). It was found that Paclitaxel and NPDP have anti-proliferative activity in MCF-7-overexpressing breast cancer cells through cell cycle arrest. Previous studies indicated that flavonoids inhibit cell proliferation via cell cycle at G2/M phase (Zhang et al., 2018; Wei et al., 2019)

This study also showed that after treatment with $\mathrm{Pa}$ clitaxel-NPDP, the percentage of cells in G2/M phase significantly increased from $36 \%$ to $65 \%$. We demonstrated for the first time that NPDP has anti-cancer effects by inducing of $\mathrm{G} 2 / \mathrm{M}$ cell cycle arrest and inhibiting cell proliferation. This data indicated that NPDP is 
a

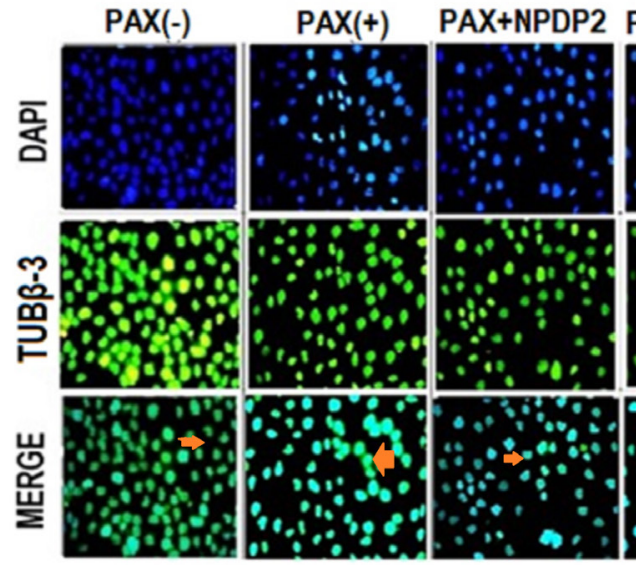

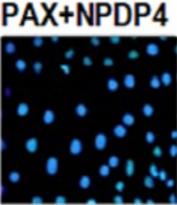
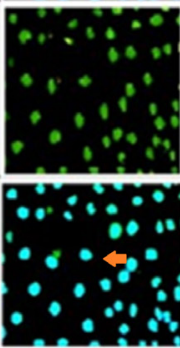
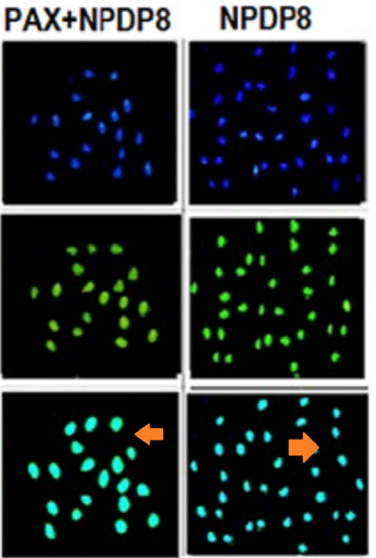

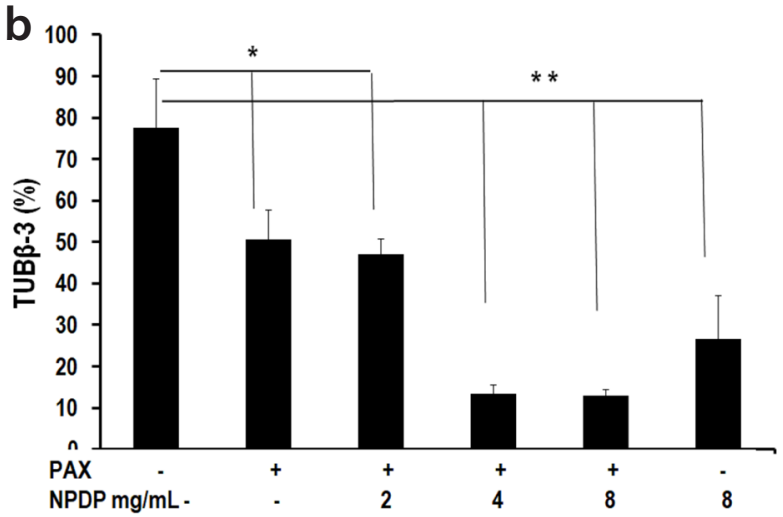

Figure 6. The combination therapy of NPDP with paclitaxel reduced the expressions of TUBB3 in MCF-7 cells.

(a) MCF-7 cells were treated with single paclitaxel or in combination with NPDP 2,4 , and $8 \mathrm{mg} / \mathrm{mL}$, respectively. Red arrow: TUBB3 positive cells. All images were magnified in representative four independent experiments. (b) The number of TUBB3 positive cells. Results are mean values \pm SD from four independent experiments. ${ }^{*} P<0.05,{ }^{*} P<0.001$ versus control group.

able to induce DNA damage and lead to MCF-7 cells arrest at $\mathrm{G} 2 / \mathrm{M}$ phase.

The results of our study showed that the combination of paclitaxel and NPDP nanoparticles decrease the expressions of TUBB3 and MAP4. Although the underlying mechanism is still unclear, the evidence indicates that MAP4 is an important regulator for cancer progression. $\mathrm{Du}$ and others (Du et al., 2018) and Gómez-Conde and others (Gómez-Conde et al., 2017) reported that MAP4 plays a role in regulating the migration and proliferation of cancer cells. Quercetin inhibits polymerization of phosphocellulose-purified tubulin into microtubules which have an important role in proliferation. Jiang, et al (2016); Jungwhoi and Jae (Jungwhoi and Jae 2016) reported that the $\beta$-subunit of tubulin in microtubules has a paclitaxel binding site that suppresses dynamic instability of the microtubules. Some researchers have shown that cancer cells are more susceptible to DNA- damaging-agents when MAP4 is not controlled (Parker et al., 2014; Li et al., 2015; Xia et al., 2018). These indicated that MAP4 induce the proliferation of breast cancer cells via microtubule dynamics regulation. MAP4 plays an important role in microtubule assembly and stabilization (Endharti et al., 2018; Jungwhoi et al., 2016; Permana et al., 2018; Permana et al., 2005). When the combinations treatments were applied, TUBB3 and MAP4 expressions were lower than single treatment $(P<0.001)$. TUBB3 is also involved in tumor development and disease aggressiveness (Chiao et al., 2013; Permana et al., 2019; Zhenhua et al., 2015). These findings suggested that TUBB3 has a function as a factor in cancer survival. This is consistent with a previous study showing that Dendropthoe pentandra can inhibit proliferation activity in colon cancer in vivo and in vitro (Endharti et al., 2016; Endharti et al., 20181a; Endharti et al., 2018b).

TUBB3, which is made up of microtubules, plays a role in cellular processes such as mitosis, proliferation, and cell motility (Person et al., 2017; Sadeghi et al., 2015; Zhenhua et al., 2015; Karki et al., 2014). The TUBB3 expression has a significant cycle-specificity in cell proliferation, of which the expression is increased in the G2-M phase (Endharti et al., 2018; Junhui et al., 2019; Permana et al., 2018; Sadeghi et al., 2015). The effect of paclitaxel and NPDP combination in TUBB3 and MAP4 expressions can be considered as a potential factor in cancer therapy. This finding suggested that the NPDP established mainly anti-effects in three ways: inhibits the growth of MCF-7 cancer cells, inhibits tubulin dimerization on microtubules and causes the arrest of the G2/M in cell cycle.

\section{CONCLUSIONS}

In conclusion, combination of paclitaxel and NPDP nanoparticles can induce cytotoxicity and is able to reduce TUBB3 and MAP4 expressions in MCF-7 breast cancer. This finding may be a promising method for a new concept of anti-cancer therapy, especially in the treatment of breast cancer.

\section{Conflicts of Interest}

The authors declare that they have no conflict of interests.

\section{REFERENCES}

Abdulkareem IH (2013) Aetio-pathogenesis of breast cancer. Niger. Postgrad. Med. J 54: 371-375. https://doi.org/10.1006/scbi.2001.0381

Agarwal M, Agarwal MK, Shrivastav N, Pandey S, Das R, Gaur P (2018) Preparation of chitosan nanoparticles and their in-vitro characterization. Int. J. Life. Sci. Scienti. Res 4: 1713-1720. https://doi. org/10.21276/ijlssr.2018.4.2.17

Chandirika JU, Sindhu R, Selvakumar S, Annadurai G (2018) Herbal extract encapsulated in chitosan nanoparticle: a novel strategy for the treatment of urolithiasis. Indo Am. J. Pharm 05: 1955-1961. https://doi.org/10.5281/zenodo.1212445

Artanti N, Firmansyah T, Darmawan A (2012) Bioactivities evaluation of Indonesian mistletoes (Dendrophthoe pentandra (L) Miq.) leaves extracts. J. Appl. Pharm. Sci 2: 24-27 
a

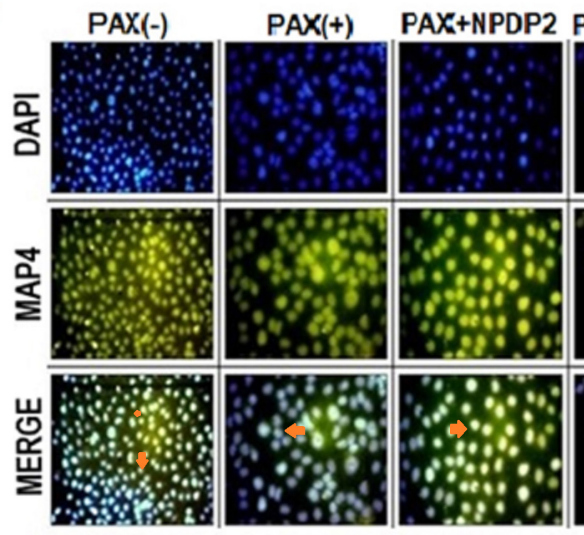

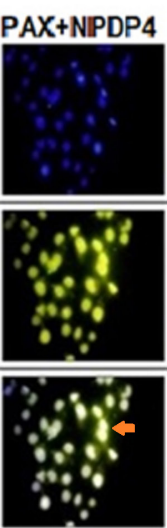

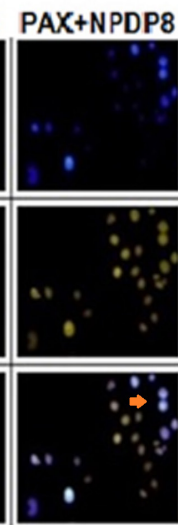

NPDP8

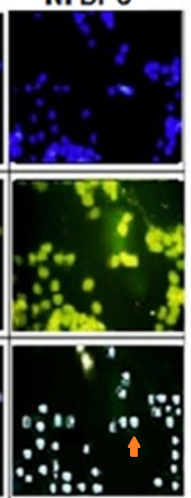

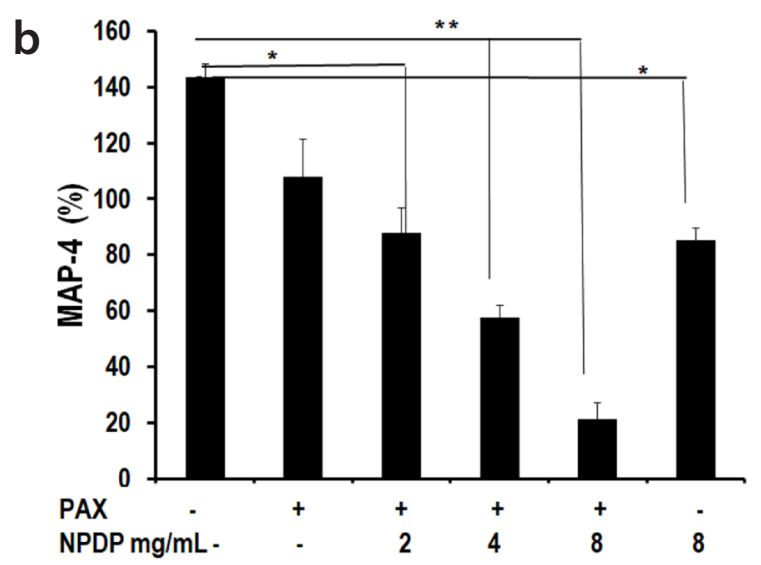

Figure 7. The combination therapy of NPDP with paclitaxel reduced the expressions of MAP4 in MCF-7 cells.

(a) MCF-7 cells were treated with paclitaxel single or combinations with NPDP 2, 4, and $8 \mathrm{mg} / \mathrm{mL}$, respectively. Red arrow: MAP4 positive cells. All images were magnified in representative four independent experiments. (b) The number of MAP4 positive cells. Results are mean values \pm SD from four independent experiments. ${ }^{*} P<0.05{ }^{* *} P<0.001$ versus control group.

Calaf G, Ponce-Cusi R, Carrion F (2018) Curcumin and paclitaxel induce cell death in breast cancer cell lines. Oncol. Rep. 40: 2381-2388. https://doi.org/10.3892/or.2018.6603

Chiao-WL, Pei-Ni C. Mu-KC (2013) Kaempferol reduces matrix metalloproteinase-2 expression by down-regulating ERK1/2 and the activator protein-1 signaling pathways in oral cancer cells. PLoS ONE 8: 1-9. https://doi.org/10.1371//ournal.pone.0080883

Cordero LB, Alkorta I, Arana L (2019) Application of solid lipid nanoparticle to improve the efficiency of anticancer drugs. Nanomaterials 9: 1-20. https://doi.org/10.3390/nano9030474

Da Silva SB, Amorim M, Pedro F, Madureira R, Ferreira D, Pintado M, Sarmento B (2015) Natural extracts into chitosan nanocarriers for rosmarinic acid drug delivery. Pharm. Biol. 53: 642-652. https://doi. org $/ 10.3109 / 13880209.2014 .935949$

Da Silva SB, Oliveira A, Ferreira D, Sarmento B, Pintado, M (2013) Development and validation method for simultaneous quantification of phenolic compounds in natural extracts and nanosystems. Phytochem. Analysis 24: 638-644. https://doi.org/10.1002/pca.2446

Gómez-Conde E, Díaz-Orea MA, Pimentel-Morales A, Cárdenas-Perea ME, Galicia-Zamalloa AL, et al (2017) MAP4 and MAP6 expression in breast cancer cell lines. Int. J. Clin. Exp. Pathol. 10: 7017-7022

El aziz A, Mohamed AR, Al-Othman MR, Mahmoud MA, Shehata SM, Abdelazim NS (2018) Chitosan nanoparticles as a carrier for Mentha longifolia extract: synthesis, characterization, and antifungal activity. Curr. Sci. 114: 2116-2122. https://doi.org/10.18520/cs/ v114/i10/2116-2122

Endharti AT, Permana S (2017) Extract from mango mistletoes Dendrophthoe pentandra ameliorates TNBS-induced colitis by regulating $\mathrm{CD}^{+} \mathrm{T}$ cells in mesenteric lymph nodes. BMC Comp. Altern. Med. 17: 1-8. https://doi.org/10.1186/s12906-017-1973-z

Endharti AT, Sulastri E, Umanailo R, Yunialce, Nurseta T, Handono K (2018a) Mango mistletoe Dendrophthoe pentandra leaf extract acts synergistically with 5 -Fluorouracil to induce apoptosis and increase p21 expression in human cervical adenocarcinoma HeLa cells by re- ducing survivin expression. J. Appl. Pharm. Sci. 8: 010-015. https:// doi.org/10.7324/JAPS.2018.8702

Endharti AT, Wahyuningtyas TE, Hardini, Handono K, Widjajanto E, Permana S (2018b) Dendrophthoe pentandra leaves extract promotes apoptotic effects of doxorubicin in human breast cancer cell via modulation of intracellular calcium and survivin. J. App. Pharm. Sci. 8: 39-43. https://doi.org/10.7324/ JAPS.2018.8806

Endharti AT, Wulandari A, Listyana A, Norahmawati E, Permana S (2016) Dendrophthoe pentandra (L.) Miq extract effectively inhibits inflammation, proliferation and induces p53 expression on colitisassociated colon cancer. BMC Comp. Altern. Med. 16: 1-8. https:// doi.org/10.1186/s12906-016-1345-0

Endharti AT, Purnamasari Y, Primasari R, Poeranto S, Permana S (2019) Coelomic fluid of lumbricus rubellus synergistically enhances cytotoxic effect of 5 -fluorouracil through modulation of focal adhesion kinase and p21 in HT-29 cancer cell line. Sci. World J. 2019: 1-9. https://doi.org/10.1155/ 2019/5632859

Ibezim EC, Andrade CT, Marcia C, Barretto B, Odimegwu DC, De Lima FF (2011) Ionically cross-linked chitosan/tripolyphosphate microparticles for the controlled delivery of pyrimethamine. Ibnosina. J. Med. BS. 201: 143-154

Jiang YY, Shang L, Shi ZZ, Zhang TT, Ma S, Lu CC, Zhang Y (2016) Microtubule-associated protein 4 is an important regulator of cell invasion/migration and a potential therapeutic target in esophageal squamous cell carcinoma. Oncogene 35: 846-856. https://doi. org/10.1038/onc. 2016.17

Jungwhoi L, Jae HK (2016) Kaempferol inhibits pancreatic cancer cell growth and migration through the blockade of EGFR-related pathway in vitro. PLoS One 11: 1-14. https://doi.org/10.1371/journal. pone. 0155264

Junhui Z, Lingfei L, Qiong Z (2019) Phosphorylation of microtubule-associated protein 4 promotes hypoxic endothelial cell migration and proliferation. Front. Pharmacol. 10: 1-13. https://doi. org/10.3389/fphar.2019.00368

Karki R, Ferlini C (2014) Class III beta-tubulin, drug resistance and therapeutic approaches in cancers. Atlas Genet. Cytogenet. Oncol. Haemato. 18: 865-871. https://doi.org/10.4267/2042/54174

Li SZ, Qiao SF, Zhang JH, Li K (2015) Quercetin increase the chemosensitivity of breast cancer cells to doxorubicin via PTEN/Akt pathway. Anticancer Agents Med. Chem. 15: 1185-1189. https://doi. org/10. 2174/1871520615999150121121708

Parker AL, Kavallaris M, McCaroll JA (2014) Microtubules and their role in cellular stress in cancer. Front Oncol 4: 1-19. https://doi. org $/ 10.3389 /$ fonc. 2014.00153

Permana S, Hadi RP, Norahmawati E, Endharti AT (2019) Coelomic fluid of Lumbricus rubellus enhances anti-prolioniferative effect of 5-fluorouracil by modulating focal adhesion kinase express and IL-1 $\beta$ of colorectal cancer in mice. J. Appl. Pharm. Sci. 9: 041-046. https:// doi.org/10.7324/JAPS.2019.90806

Permana S, Pearlindah, Sholihah Z, Iskandar A, Susanti H, Endharti AT (2018) Cytotoxic effects and anti-proliferative cancer activity of coelomic fluid from Lumbricus rubellus promotes apoptosis and reduces G2/M phase progression in HT-29 cells. J. Appl. Pharm. Sci. 8: 028-034. https://doi.org/10.7324/JAPS.2018.81104

Person F, Wilczak W, Hube-Magg C, Burdelski C, Möller-Koop C, Simon R, Noriega M, Sauter G, Steurer S, Burdak-Rothkamm S, Jacobsen F (2017) · Prevalence of BIII-tubulin (TUBB3) expression in human normal tissues and cancers. Tumour Biol. 39: 1-11. https://doi.org/10.1177/1010428317712166

Rampino A, Borgogna M, Blasi P, Bellich B, Cesàro A (2013) Chitosan nanoparticles: preparation, size evolution and stability. Int. J. Pharm. 455: 219-228. https://doi.org/10.1016/j.ijpharm.2013.07.034

Sadeghi I, Behmanesh M, Ahmadian Chashmi N, Sharifi M, Soltani BM (2015) 6-methoxy podophyllotoxin induces apoptosis via inhibi- 
tion of TUBB3 and TOPIIA gene expressions in 5637 and K562 cancer cell lines. Cell. J. 2017: 502-509. https://doi.org/10.22074/ cellj. 2015.10

Sibaud V, Lebœuf NR, Roche H, Belum VR, Gladieff L, Deslandres M, Montastruc M, Eche A, Vigarios E, Dalenc F, Lacouture ME (2016) Dermatological adverse events with taxane chemotherapy. J. Eur. Acad. Dermatol. 26: 427-443. https://doi.org/10.1684/ ejd.2016.2833

Wei WL, Hou JJ, Wang X, Yu Y, Li HJ, Li ZW, Feng ZJ, Qu H, Wu WY, Guo DA (2019) Venenum bufonis: an overview of its traditional use, natural product chemistry, pharmacology, pharmacokinetics, and toxicology. J. Ethnopharmacol. 237: 215-35. https://doi. org/10.1016/j.jep.2019.03.042

Xia X, He C, Wu A, Zhou J, Wu J (2018) Microtubule-associated protein 4 is a prognostic factor and promotes tumor progression in lung adenocarcinoma. Dis. Markers 2018: 1-8. https://doi.org/10. $1155 / 2018 / 8956072$
Zhang HW, Hu JJ, Fu RQ, Liu X, Zhang YH, Li J, Liu L, Li YN, Deng Q, Luo QS, Ouyang Q, Gao N (2018) Flavonoids inhibit cell proliferation and induce apoptosis and autophagy through downregulation of $\mathrm{PI} 3 \mathrm{~K} \gamma$ mediated $\mathrm{PI} 3 \mathrm{~K} / \mathrm{AKT} / \mathrm{mTOR} / \mathrm{p} 70 \mathrm{~S} 6 \mathrm{~K} / \mathrm{ULK}$ signaling pathway in human breast cancer cells. Sci. Rep. 8: 1-13. https://doi.org/10.1038/s41598-018-29308-7

Zhang J, Li L, Zhang Q, Yang X, Zhang C, Zhang X (2019) Phosphorylation of microtubule-associated protein 4 promotes hypoxic endothelial cell migration and proliferation. Front. Pharmacol. 10: 1-13. https://doi.org/10.3389/fphar.2019.00368

Zhenhua Y, Ying L, Changzheng S (2015) Suppression of PTEN/ AKT signalling decreases the expression of TUBB3 and TOP2A with subsequent inhibition of cell growth and induction of apoptosis in human breast cancer MCF-7 cells via ATP and caspase-3 signaling pathways. Anticancer Agents Med. Chem. 15: 1185-1189. https:// doi.org/10.3892/or.2017.5358 